\title{
Pengelolaan Gua Cerme Sebagai Daya Tarik Wisata Berkelanjutan
}

Viona Amelia1,a, Danang Prasetyo ${ }^{2, a}$

${ }^{1}$ vionaamelia@stipram.ac.id, ${ }^{2}$ danangprasetyo@stipram.ac.id

aSekolah Tinggi Pariwisata Ambarrukmo Yogyakarta, Jln. Ahmad Yani No. 52, Ring Road Timur Yogyakarta 55198, Indonesia

\section{Abstract}

Cerme Cave is one of the objects of special interest tourist attraction which is used as one of the non-coastal tourism development projects by the dinas pariwisata kabupaten Bantul. This is done so that the distribution of tourists who visit, can be distributed evenly across all attractions in the Bantul regency. The decline in the level of tourist visits, limited attractions, and double levies has become an obstacle to the development of the Cerme Cave attraction, so a number of recommendations are needed to overcome and make these attractions sustainable. The research model used is qualitative through exploratory studies. The results showed that the problems that arose in these attractions include, dualism of management, the number of tourists being a priority, community participation is still low, lack of knowledge about tourism management in accordance with sustainable tourism management guidelines, do not have the intended target market, and marketing and limited promotions. Special interest tourism management strategies, including the targeted tourism segments must be clear, adequate human resource readiness in quality and quantity, facility development and accessibility in accordance with the landscape and tourist needs, promotions in accordance with the theme of tourist attraction attractions, so that the development strategy of Cerme Cave can be implemented optimally.

Keywords: sustainable tourism, cerme cave, management.

\section{PENDAHULUAN}

Gaung pariwisata Indonesia di kancah dunia telah membuktikan bahwa bangsa kita kaya akan potensi sumber daya pariwisata. Laut, sungai, danau, gunung, hutan, dolin, hingga gua menunjukkan bahwa kekayaan bentang alam Indonesia sangatlah beragam. Bentang alam gua menjadi salah satu warisan geologi yang tidak hanya terpaku pada keunikan dan kekhasannya, tetapi juga memiliki kekayaan sumber daya alam baik itu hayati maupun hon hati (ksdae.menlhk.go.id). Kumar (2014) mengungkapkan tentang munculnya aktifitas susur gua (caving) sebagai kegiatan pariwisata, yakni "In 1940s and 1950s, a substantial caving community developed in the United States and at the same time cave tourism or caving became popular".

Sementara di Indonesia, aktifitas susur gua muncul pada awal tahun 1980 (Adji dkk, 1999). Salah satu gua yang populer dikalangan penggemar aktifitas susur gua adalah Gua Cerme. Keberadaan gua ini membentang diantara dua kabupaten yakni Kabupaten Bantul dan Kabupaten Gunung Kidul. Gua ini menjadi salah satu proyek pengembangan objek daya tarik wisata selain objek wisata pantai yang sedang dikerjakan oleh Pemerintah Kabupaten Bantul. Upaya ini dilakukan untuk meningkatkan dan pemerataan kunjungan wisatawan ke berbagai objek daya tarik wisata di Kabupaten Bantul. Gua Cerme diresmikan sebagai objek wisata pada tahun 1990, dalam perkembangannya dari tahun ke tahun objek daya tarik ini perlu pengelolaan yang maksimal untuk menarik kunjungan wisatawan.

Sampai saat ini, pelaksanaan pengembangan gua sebagai objek daya tarik wisata masih terdapat banyak kekurangan dalam infrastruktur maupun sumber daya manusia. Sebagai pengelola yang bertanggung jawab terhadap keberlangsungan kegiatan masyarakat dan wisatawan masih memiliki beberapa kekurangan. Hal ini berdampak terhadap kurang maksimalnya pengelolaan sumber daya alam dan budaya sebagai objek wisata.

Kurangnya kesadaran terhadap pengelolaan objek daya tarik secara berkelanjutan turut mempengaruhi peringkat pariwisata Indonesia dalam World Economic Forum (WEF) Travel and Tourism Competitiveness Index 2010 (ILO, 2012:11). Terdapat 5 aspek kelemahan utama yang menjadi penghambat pariwisata di Indonesia, diantaranya adalah kebijakan \& regulasi, keamanan \& keselamatan, kesehatan, pariwisata berkelanjutan, serta, teknologi informasi \& komunikasi (ILO, 2012:12). Sejumlah masalah tersebut ada yang terindikasi dualisme pengelolaan, keterbatasan sarana prasarana, keterbatasan atraksi, keterbatasan lahan parkir dan sebagainya. Untuk 
memperbaiki mekanisme pengelolaan terhadap objek tersebut, maka diperlukan evaluasi terhadap pengelolaan objek daya tarik Gua Cerme supaya ditinjau kembali untuk mengetahui permasalahan-permasalahan yang menjadi faktor penghambat pengelolaan objek daya tarik secara keberlanjutan. Merujuk pada latar belakang permasalahan mengenai pengelolaan objek daya tarik secara berkelanjutan, tujuan penelitian ini adalah untuk mengetahui "Bagaimana pengelolaan objek daya tarik wisata Gua Cerme berdasarkan pedoman pengelolaan destinasi berkelanjutan?".

\section{TINJAUAN PUSTAKA}

\section{A. Wisata Gua dalam Ranah Pariwisata Berkelanjutan}

United Nation World Tourism Organization (UNWTO) mendefinisikan pariwisata berkelanjutan atau sustainable tourism sebagai aktifitas pariwisata yang sangat memperhatikan dampak secara ekonomi, sosial, maupun lingkungan, pada masa sekarang hingga yang akan datang, untuk memenuhi kebutuhan pengunjung, industri pariwisata, lingkungan dan komunitas lokal (ILO, 2012). Wisata gua merupakan salah satu dari wujud pariwisata yang berkelanjutan dan memperkaya karakter geografis suatu tempat, lingkungan, warisan, estetika, budaya, dan kesejahteraan penghuninya (Okonkwo et al, 2017:19). Aktifitas wisata yang berorientasi pada wisata rekreasional yang unik dan berkualitas menjadi konsep ideal, yakni sinergi antara aktifitas berwisata yang bertanggung jawab sehingga kelestarian lingkungan terjaga. Wisata gua memiliki kedudukan penting dalam industri pariwisata apabila dimanfaatkan dan dikembangkan dengan benar karena akan meningkatkan manfaat ekonomi, sosial dan lingkungan bagi masyarakat lokal. Konsep pengelolaan wisata berkelanjutan tentunya dapat terwujud dengan memahami dan mengaplikasikan peraturan perundangan yang berlaku.

Berdasarkan Perda Provinsi DIY No. 1 Tahun 2012, yang secara rinci dituangkan dalam bagian lampiran, terdapat 4 indikasi program pengembangan Goa Cerme sebagai kawasan wisata susur goa. Indikator tersebut adalah pengembangan wisata susur gua; pengembangan event wisata berbasis budaya dan cinderamata; pengembangan area berkemah; dan pengembangan objek ekowisata dengan konsep susur goa.

Berdasarkan program tersebut dapat diketahui bahwa arah pengembangan kawasan Gua Cerme adalah ekowisata yang dikemas dalam aktifitas susur gua. Konsep pengembangan berbasis ekowisata merupakan sebuah pendekatan pengelolaan pariwisata tanpa mengeksploitasi alam, kearifan lokal diperkenalkan dan masyarakat setempat diberdayakan untuk memenuhi kebutuhan pengetahuan, fisik dan psikologis wisatawan (Fandeli, 2000).

\section{B. Pengelolaan Pariwisata Berkelanjutan}

Pedoman Destinasi Berkelanjutan yang disusun dalam Permen No.14 Tahun 2014 memberikan acuan yang komprehensif mengenai tata kelola destinasi pariwisata secara berkelanjutan. Melalui pedoman tersebut, setiap pengelola mampu melaksanakan perlindungan, pemanfaatan dan pengembangan kawasan sebagai destinasi pariwisata yang berkelanjutan. Pengelolaan destinasi berkelanjutan mencakup empat aspek yakni, perencanaan, pengelolaan, pemantauan dan evaluasi. Keempat kriteria tersebut yang menjadi dasar dalam pembangunan kepariwisataan, dan keseimbangan yang sesuai harus dibentuk untuk menjamin keberlanjutannya dalam jangka panjang. Adapun penjelasan mengenai keempat kriteria tersebut sebagai berikut ini.

\section{Kriteria perencanaan mencakup:}

a. Strategi destinasi berkelanjutan mencakup pengembangan aksesibilitas, amenitas, serta aktivitas pariwisata di kawasan destinasi yang disesuaikan dengan daya dukung lingkungan (carrying capacity), pertumbuhan ekonomi, isu sosial-budaya, kualitas atraksi yang disajikan, kesehatan \& keselamatan wisatawan, serta estetika.

b. Pengaturan perencanaan, yakni prosedur perencanaan yang meliputi perkiraan/estimasi terhadap dampak lingkungan yang akan muncul, berikut dengan dampak yang akan berimbas pada sektor ekonomi, sosial, zonasi dan pemanfaatan lahan, desain konstruksi serta pembongkaran dengan melibatkan masyarakat setempat sebagai upaya 
melindungi sumber daya alam dan budaya.

c. Standar keberlanjutan, merupakan sebuah standar sistem pengelolaan pariwisata berkelanjutan yang mengatur aspek penting bagi pelaku usaha pariwisata, seperti pengelola objek/destinasi wisata, pengelola akomodasi, tur operator dan lainnya.

\section{Kriteria pengelolaan mencakup:}

a. Organisasi manajemen destinasi yang efektif dan terkoordinasi baik dalam hal pendanaan maupun pembagian tugas, serta adanya keterlibatan sektor swasta dan publik sesuai landasan hukum yang berlaku.

b. Pengelolaan pariwisata musiman, yakni strategi pemasaran dalam bentuk kalender wisata untuk memetakan peluang pariwisata sepanjang tahun, guna menstabilkan perekonomian dan pendapatan masyarakat lokal, budaya dan kawasan destinasi.

c. Akses bagi semua kalangan yakni kebijakan dalam rangka pemenuhan akses menuju lokasi wisata bagi seluruh wisatawan termasuk wisatawan disabilitas.

d. Akuisisi properti, adanya hukum atau peraturan perundangan yang mengatur tentang akuisisi properti atau kepemilikan aset sesuai hukum adat melalui persetujuan masyarakat lokal serta memberikan ganti rugi yang sesuai.

e. Keselamatan dan keamanan, merupakan suatu sistem terpadu guna mencegah, memantau, melaporkan serta menangani permasalahan yang berkaitan dengan keselamatan dan keamanan wisatawan termasuk didalamnya adalah higienitas, kebakaran, kelistrikan, serta moda transportasi umum.

f. Manajemen krisis dan kedaruratan, yakni pengelolaan sistem tanggap darurat melalui peran sumber daya manusia dan finansial sebagai kunci dalam mengatasi krisis, serta prosedur penanganan selama situasi darurat berlangsung hingga selesai.

g. Promosi, promosi pariwisata dilakukan tepat sasaran, sesuai dengan kearifan lokal/otentik, serta bertanggungjawab dan menghormati wisatawan.

\section{Kriteria pemantauan mencakup:}

a.Monitoring, yakni sistem pemantauan dan evaluasi kawasan pariwisata yang mencakup isu sosial, budaya, ekonomi, lingkungan, hak asasi manusia hingga prosedur mitigasi terkait dampak yang dituimbulkan oleh aktifitas pariwisata yang dilaksanakan dan dilaporkan secara berkala.

b. Pendataan aset \& atraksi pariwisata, berkaitan dengan aktifitas pencatatan mengenai kepemilikan aset dan atraksi pariwisata yang harus diperbaharui setiap tahun.

\section{Kriteria evaluasi mencakup:}

a.Adaptasi perubahan iklim, berkaitan dengan adanya kebijakan terhadap perubahan iklim, prosedur untuk mengurangi resiko hingga programprogram yang disosialisasikan untuk meningkatkan kesadaran masyarakat, dan usaha yang bergerak dalam bidang pariwisata.

b. Kepuasan pengunjung, berkaitan dengan sistem untuk memantau dan melaporkan tingkat kepuasan atau penanganan terhadap keluhan, melalui prosedur wawancara/survei pada wisatawan. Hasil survei tersebut digunakan sebagai landasan penyusunan perencanaan aksi untuk meningkatkan tingkat kepuasan pengunjung.

\section{METODE PENELITIAN}

Objek daya tarik gua Cerme yang merupakan objek dalam penelitian ini terletak di dusun Srunggo, desa Selopamioro, kecamatan Imogiri, kabupaten Bantul, Yogyakarta. Penelitian ini menggunakan model penelitian kualitatif melalui studi evaluasi yakni pengumpulan data lapangan kemudian dibandingkan dengan kriteria yang telah ditentukan (Usman \& Akbar, 2014 : 144). Tujuannya untuk mengetahui pelaksanaan pengelolaan gua Cerme yang telah dilakukan oleh Dinas Pariwisata Kabupaten Bantul sebagai salah satu pengelola, serta bertujuan untuk memperbaiki sistem pengelolaan objek 
daya tarik gua Cerme supaya dapat dikelola sesuai dengan prinsip-prinsip berkelanjutan. Metode yang digunakan dalam penelitian ini yakni metode kualitatif, metode tersebut dipilih guna mengetahui kondisi objek sesuai dengan realita. Metode kualitatif digunakan sebagai sarana pengumpulan data agar memperoleh fakta mutakhir pada saat penelitian di lapangan (Sugiyono, 2014).

Penelitian ini menggunakan dua sumber data yakni, data primer dan data sekunder. Data primer sebagai sumber data yang langsung diberikan kepada pengumpul data (Sugiyono, 2007:137) yakni melalui data yang diperoleh dari narasumber melalui wawancara (in-depth interview) dengan Bapak Agus Yuli selaku Kapala Bidang Destinasi, Bapak Joko selaku Kepala Seksi Objek Daya Tarik Wisata, dan Bapak Wijdan selaku staff Bidang Destinasi. Narasumber tersebut selaku informan kunci yang berperan aktif dalam pengembangan dan pemberdayaan masyarakat di kawasan objek daya tarik Gua Cerme, dengan membawa daftar checklist dan tape recorder sebagai alat dokumentasi. Sementara itu, data sekunder dikumpulkan melalui berbagai sumber literatur yang berkaitan atau sesuai dengan kebutuhan penelitian yang bersumber dari literatur, bukubuku, serta dokumen perusahaan (Sugiyono, 2007: 139).

Penelitian ini menggunakan interactive model dari Milles \& Huberman (1992:20) sebagai teknik klasifikasi data melalui tiga tahap:

1. Reduksi data (data reduction) yang merupakan proses memilih, menyederhanakan dan mengubah data yang muncul dari catatan yang diperoleh di lapangan.

2. Penyajian data (display data), data yang telah tersusun kemudian disajikan dalam bentuk teks naratif, sehingga dapat dilakukan tindakan hingga penarikan kesimpulan.

3. Penarikan kesimpulan (verification), verifikasi atau penarikan kesimpulan dilakukan melalui pemeriksaan kembali reduksi data dan/atau penyajian data dengan tujuan menghindari penarikan kesimpulan yang menyimpang.

\section{HASIL PENELITIAN DAN PEMBAHASAN}

Kawasan wisata susur Gua Cerme terletak di antara dua wilayah administratif yakni dusun Srunggo, Desa Selopamioro, Kecamatan Imogiri, Kabupaten Bantul dengan Dusun Ploso, Desa Giritirto, Kecamatan Panggang, Kabupaten Gunungkidul, Daerah Istimewa Yogyakarta. Berdasarkan hasil wawancara dengan pihak Dinas Pariwisata Kabupaten Bantul, pengembangan Gua Cerme sebagai objek daya tarik wisata diinisiasi oleh CV. Samajaya pada tahun 1990. CV. Samajaya memiliki andil dalam pengelolaan dan pembangunan sarana dan prasarana Gua Cerme, hingga kemudian pengelolaan objek daya tarik tersebut diambil alih sepenuhnya oleh Pemerintah Kabupaten Bantul dan Pemerintah Kabupaten Gunung Kidul sampai saat ini. Aktifitas wisatawan atau pengunjung yang datang ke objek wisata Gua Cerme adalah susur gua dan nenepi (bertapa) di gua yakni Gua Kaum, Gua Dalang, Gua Badut. Panjang gua kurang lebih 1,2 km ditempuh 1,52 jam. Pintu masuk di Dusun Srunggo (Bantul) dan pintu keluar di Dusun Ploso (Gunung Kidul). Aktifitas susur gua ini perlu didampingi pemandu profesional dan berpengalaman karena di dalam gua terdapat 7 cabang, dan 1 cabang yang berbahaya karena minim oksigen. Fasilitas susur Gua yang tersedia adalah helm 40 buah (meskipun bukan helm standar susur gua), sepatu boots 25 buah, dan headlamp/senter 40 buah. Tarif pemandu susur gua yakni $50 \mathrm{ribu/orang}$, untuk peserta $\leq 15$ orang dikenakan tarif dan tarif 3 ribu/orang ditambah biaya sewa peralatan untuk peserta $\geq 15$ orang.

Keberadaan dualisme dalam pengelolaan objek daya tarik Gua Cerme justru menjadi penghambat pengembangan objek daya tarik wisata tersebut. Bapak Nono sebagai ketua Pokdarwis (kelompok sadar wisata), mengatakan bahwa jumlah kunjungan harian Gua Cerme kurang lebih 5 sampai 20 wisatawan pada saat hari biasa (weekday) dan 60 sampai 70 wisatawan khusus di hari Sabtu dan Minggu (weekend). Segmen wisatawan yang berkunjung pada umumnya adalah siswa sekolah dan mahasiswa pencinta alam (Mapala). Berikut adalah laporan jumlah kunjungan wisatawan dan pendapatan Gua Cerme tahun 2019-2020. 


\begin{tabular}{l|c|c|c|c}
\multirow{2}{*}{ BULAN } & \multicolumn{2}{c}{ Statistik Pengunjuk Goa Cerme Tahun 2019 dan 2020} \\
\cline { 2 - 5 } & Pengunjung & Pendapatan & Pengunjung & Pendapatan \\
\hline Januari & 613 & 3.524 .750 & 290 & 1.667 .500 \\
\hline Februari & 556 & 3.197 .000 & 251 & 1.443 .250 \\
\hline Maret & 298 & 1.713 .500 & 104 & 598.000 \\
\hline April & 487 & 2.800 .250 & $-*$ & $-*$ \\
\hline Mei & 237 & 1.362 .750 & $-*$ & $-*$ \\
\hline Juni & 708 & 4.071 .000 & $-*$ & $-*$ \\
\hline Juli & 1.230 & 7.072 .500 & $-*$ & $-*$ \\
\hline Agustus & 328 & 1.886 .000 & - & - \\
\hline September & 585 & 3.363 .750 & - & - \\
\hline Oktober & 363 & 2.087 .250 & - & - \\
\hline Nopember & 538 & 3.093 .500 & - & - \\
\hline Desember & 885 & 5.088 .750 & - & - \\
\hline JUMLAH & $\mathbf{6 . 8 2 8}$ & $\mathbf{3 9 . 2 6 1 . 0 0 0}$ & $\mathbf{6 4 5}$ & $\mathbf{3 . 7 0 8 . 7 5 0}$ \\
& Sumber: pariwisata.bantulkab.go.id &
\end{tabular}

*(tidak ada data mengenai kunjungan wisatawan dan pendapatan pada bulan April-Juni, sebagai dampak pandemi Covid-19)

Berikut adalah hasil penelitian tentang pengelolaan objek daya tarik wisata Gua Cerme berdasarkan pedoman pengelolaan destinasi yang berkelanjutan yang diatur dalam Peraturan Menteri No. 14 tahun 2016 penulis paparkan dalam bentuk tabel berikut ini.

Tabel. 2

Hasil Penelitian Pengelolaan Objek Wisata Goa Cerme

No

Bukti pendukung

Kriteria

Strategi Pengembangan Objek Daya Tarik Berkelanjutan

Dinas Pariwisata Kab. Bantul selaku pengelola diharapkan telah menyusun dan melaksanakan strategi untuk kepentingan pengembangan objek daya tarik Gua Cerme, dengan mempertimbangkan aspek lingkungan, ekonomi, sosial, budaya, kualitas daya tarik, kesehatan kawasan wisata, keselamatan pengunjung, serta partisipasi masyarakat.

Objek daya tarik Gua Cerme termuat dalam Rencana Tata Ruang Wilayah (RTRW) Kabupaten Bantulsebagai kawasan peruntukan pariwisata alam (pasal 59 ayat $3 \mathrm{~d}$ ).

Objek daya tarik Gua Cerme termuat pada Rencana Induk Pembangunan Kepariwisataan Daerah (RIPPARDA).

Dinas Pariwisata Kab. Bantul belum memiliki dokumen mengenai RIPPAR Berkelanjutan.

Dinas Pariwisata Kab. Bantul memilikidokumenRIPPARDA; Renstra; RTRW yang dapat diakses oleh masyarakat melalui website Dinpar Bantul atau Bappeda.

Objek daya tarik wisata Gue Cerme merupakan objek bagianRIPPARDA yang dikembangkan melalui konsultasi dengan masyarakat.

Salah satu program Dinpar Kab. Bantul menjadikan pariwisata Gua Cerme menjadi salah satu objek unggulan non pantai.

Alokasi anggaran untuk tahun 2019untuk pengembangan objek daya tarik wisata sebagian dialihkan untuk pelaksanaan Pilkada tahun 2019.

Proses perencanaan hingga evaluasi terkait pengembangan objek daya tarik Gua Cerme melibatkan seluruh pemangku kepentingan.

Pelaksanaan 
Dinas Pariwisata kab. Bantul selaku pengelola diharapkan telahmemiliki panduan perencanaan dan atau kebijakan berkaitan dengan dampak yang akan ditimbulkan dari aktifitas pariwisata. Panduan tersebut dirancang dan disusun dengan melibatkan masyarakat lokal guna melindungi sumber daya alam dan budaya.

Dinas Pariwisata Kab. Bantul memilikiRIPPARDA, Renstra, Perda RTRWserta programprogram lain sebagai arah/ landasan pengembangan objek daya tarik Gua Cerme.

$\begin{array}{llll}\text { Kabupaten Bantul memiliki panduan kebijakan berkaitan dengan dampak terhadap } & \sqrt{ }\end{array}$ lingkungan, ekonomi dan sosial yang tertuang dalam Perda No 4 Tahun 2011 dan Perda No.39 Tahun 2000

Kabupaten Bantul menggunakan Perda No 4 Tahun 2011 sebagai landasan kebijakan untuk mengatur tata guna lahan, desain, konstruksi dan isu pembongkaran.

Publik dapat mengakses dan atau mengunduh pedoman/ Perda melalui website.

Kabupaten Bantul melakukan penerapan penegakan hukum.

Dinas Pariwisata Kab. Bantul selaku pengelola diharapkan telah memiliki sistem yang terintegrasi untuk mempromosikan industri pariwisata secara yang memiliki standar keberlanjutan serta menampilkan senarai perusahaan yang telah bersertifikasi yang dapat diakses oleh masyarakat.

\begin{tabular}{|l|l|l} 
Dinas Pariwisata Kab. Bantul selaku pengelola objek daya tarik wisata Gua Cerme belum & $X$
\end{tabular} memiliki sistem standar dan penilaian kesesuaian pariwisata keberlanjutan.

Regulasi yang mengatur tentang ijin usaha jasa pariwisata Kabupaten Bantul berpedoman pada $\sqrt{ }$ Perda No. 3 Tahun 2005

Tanda Daftar Usaha Pariwisata (TDUP) diterbitkan oleh Dinas Penanaman Modal dan Pelayanan Terpadu atas rekomendasi dari Dinas Pariwisata. Kawasan dari Gua Cerme yang dikelola oleh Dinpar. Kab. Bantul masuk dalam kategori usaha pengelolaan wisata alam.

Perda Kab. Bantul No. 4 Tahun 2011 telah mengatur secara detail yang tertuang pada pasal 3337 mengenai pengelolaan sampah dan limbah. Kawasan wisata Gua Cerme tergolong sebagai kawasan wisata dengan tingkat polusi dan volume sampah anorganik yang rendah.

Publikasi mengenai penerbitan TDUP oleh Dinas Penanaman Modal dan Pelayanan Terpadudapat diakses melalui website resmi, dan jika dalam jangka waktu 3 hari tidak ada keluhan atau laporan dari masyarakat terhadap calon industri pariwisata (hotel,restoran, dsb), maka Dinas Penanaman Modal dan Pelayanan Terpadu resmi mengeluarkan surat ijin tersebut.

\section{$4 \quad$ Organisasi manajemen destinasi}

Objek daya tarik wisata Gua Cerme merupakan salah objek yang dikelola oleh Dinpar. Kab Bantul. Dalam pengelolaannya melibatkan berbagai pihak termasuk di dalamnya adalah Pemda DIY, Pemkab. Bantul, Pemkab. Gunung Kidul, Institusi Pendidikan serta Pokdarwis memiliki tanggung jawab serta berkoordinasi dalam rangka pengembangan pariwisata berkelanjutan.

Pengelolaan destinasi wisata Bantul melibatkan berbagai unsur pemangku kepentingan yakni pemerintah DIY, pemkab Bantul, swasta, masyarakat, dan akademisi (penta helix). Sementara $x$ pada pengembangan objek daya tarik Gua Cerme terindikasi belum melibatkan pihak swasta.

Pembentukan penta helix pemangku kepentingan bersifat lintas sektor (melibatkan berbagai kepentingan)sebagai strategi untuk mendukung perintisan pengembangan destinasi pariwisata daerah tercantum dalam Perda Bantul No. 18 tahun 2015 tentang RIPPARDA 2015-2025 pasal 22.

Berbagai pemangku kepentingan yakni PemerintahDaerah, Pemerintah Desa, Pokdarwis dan Institusi Pendidikandalam rangka mendukung perintisan pengembangan objek daya tarik wisata Gua Cerme.

Hingga 2019 Dinpar. Kab Bantul terkendala dengan penerapan rencana aksi pembangunan pariwisata yang berkelanjutan karena keterbatasan.

Pengaturan mekanisme pendanaan pelaksanaan program didanai oleh APBD yang tercantum dalam Renstra.

\section{Pengelolaan pariwisata musiman}

Dinpar Kab. Bantul diharapkan telah memiliki strategi dan kebijakan pengelolaan pariwisata musiman, agar dapat menciptakan iklim perekonomian yang stabil bagi masyarakat lokal, menjaga eksistensi dan keberlangsungan budaya dan lingkungan, serta memetakan peluang pariwisata sepanjang tahun. Memiliki kalender even/kegiatan wisata sepanjang tahun. 
Proses perencanaan setiap kegiatan wisata di Kawasan wisata Goa Cerme telah melibatkan berbagai pemangku kepentingan (masyakarat desa sekitar Goa Cerme, Pokdarwis, perwakilan Dinas Pariwisata). Keterlibatan berbagai pihak bertujuan agar untuk memastikan keseimbangan kebutuhan ekonomi masyarakat setempat, keberlangsungan budaya dan lingkungan terpenuhi.

$6 \quad$ Akses untuk semua (Pembangunan aksesibilitas pariwisata pasal 23-24)

Akses untuk semua kalangan tertuang dalam arah kebijakan kedua dalam lampiran RIPPARDA, yakni evaluasi fasilitas kepariwisataan untuk memenuhi kebutuhan wisatawan berkebutuhan khusus (difabel). RIPPARDA Bantul 2015-2025 bagian kelima pasal 23 mengatur tentang pembangunan aksesibilitas pariwisata, namun pelaksanaan pembangunan aksesibilitas bagi wisatawan $X$ difabel di kawasan Gua Cerme belum dilakukan.

Objek daya tarik Gua Cerme belum menyediakan fasilitas dan aksesibilitas bagi wisatawan $\quad$ X berkebutuhan khusus (disabilitas).

$7 \quad$ Akuisisi properti

Kebijakan dan regulasi tentang pengambilalihan properti.

Kabupaten Bantul menggunakan Perda No. No. 4 Tahun 2011 untuk mengatur tentang pengambilalihan tanah dan bangunan serta pemanfaatan lahan adat/tradisional.

Dinpar Kab. Bantul memiliki agenda bulanan untuk melakukan monitoring dan evaluasi objek $\sqrt{ }$ daya tarik wisata.

Adanya payung hukum terkait kompensasi tanah kas desa yang tercantum dalam Perbup Bantul No. 84 Tahun 2016.

$8 \quad$ Keselamatan dan Keamanan

Memiliki sistem terintegrasi berkaitan dengan keselamatan dan keamanan kawasan wisata

Objek daya tarik wisata Gua Cerme hanya memiliki 1 pos keamanan dan P3K.

Objek daya tarik wisata Gua Cerme tidak terdapat pos keamanan polisi pariwisata.

Dinas Pariwisata Kab. Bantul melakukan pendampingan dan pelatihan secara berkala bagi anggota Pokdarwis dan masyarakat lokal yang bersedia terlibat untuk menangani isu keselamatan dan keamanan.

Warung-warung yang berada di sekitar objek daya tarik wisata Gua Cerme hanya menjual makanan kemasan yang tentunya telah memenuhi standar BPOM.

Lokasi objek daya tarik wisata belum tersedia rambu peringatan.

Objek daya tarik wisata Gua Cerme memberikan asuransi kepada wisatawan yang berkunjung sesuai dengan Peraturan Bupati Bantul No 32 Tahun 2018.

Objek daya tarik wisata Gua Cerme menyediakan perlengkapan P3K namun terbatas secara jumlah dan kelengkapan.

Objek daya tarik wisata Gua Cerme memiliki 1 pos keamanan di titik strategis.

Berdasarkan Perda Kab. Bantul No. 4 Tahun 2011 mengenai Rencana Tata Ruang Wilayah Tahun 2010-2030, dalam pasal 14 (a) tentang keberadaan terminal penumpang tipe B di Kecamatan Imogiri yang diharapkan dapat mempermudah pergerakan wisatawan yang akan berkunjung ke berbagai objek daya tarik di kawasan Imogiri termasuk Gua Cerme. Sementara untuk menuju ke lokasi objek daya tarik wisata, pengelola objek memberdayakan ojek-ojek konvensional sebagai moda transportasi umum yang dapat mengakomodir calon wisatawan yang akan berwisata ke Gua Cerme mengingat kondisi jalan menuju lokasi objek daya tarik yang cukup terjal.

Pada kawasan objek daya tarik wisata belum disediakan papan-papan petunjuk keselamatan pada lokasi strategis

\section{$9 \quad$ Manajemen Krisis dan Kedaruratan}

Dinas Pariwisata Kab. Bantul menguatkan kerjasama lintas sektor untuk menyusun perencanaan tanggap darurat sesuai dengan kondisi setiap objek daya tarik wisata. Pemyediaam sumber daya dan pelaksanaan pelatihan krisisi dan kedaruratan yang diperuntukkan bagi staf pengelola, wisatawan, maupun masyarakat setempat secara berkala.

Kebijakan mengenai penanggulangan bencana, tercantum pada PerdaKab. Bantul No. 4 Tahun 2011 mengenai Rencana Tata Ruang Wilayah Tahun 2010-2030, dalam pasal 8 (4). Sebagai daerah rawan longsor, Dinpar Kab. Bantul berencana membangun talud di kawasan wisata Gua Cerme untuk meminimalisir bencana tanah longsor, namun pada kawasan tersebut belum 
tersedia titik-titik kumpul ataupun petunjuk-petunjuk jalur evakuasi jika terjadi bencana.

Program kegiatan yang berkaitan dengan manajemen krisis dan kedaruratan tidak tercantum

dalam Renstra, sehingga tidak ada alokasi dana untuk menangani krisis dan kedaruratan.

Sumber daya manusia terbatas sehingga kurang optimal dalam penanganan krisis dan kedaruratan.

Tidak terdapat pusat krisis serta tidak ada prosedur standar penanganan pelaksanaan saat

keadaan darurat terjadi di kawasan objek daya tarik Gua Cerme.

Simulasistandar penanganan kondisi darurat belum diupayakan secara rutin.

Dokumen Standar Operating Procedure (SOP) yang diperbaharui secara berkala.

10 Promosi (Pembangunan pemasaran pariwisata pasal 29-pasal 30)

Promosi yang akurat sesuai destinasinya dan produknya, jasanya, serta kepastian pengakuan keberlanjutannya. Isi promosi memperlakukan masyarakat lokal dan wisatawan secara otentik dan rasa hormat.

Dinas Pariwisata Kab. Bantul memiliki kalender kegiatan wisata tahunan.

Dinas Pariwisata Kab. Bantul sebagai pengelola belum optimal dalam memetakan peluang untuk menyusun strategi promosi yang sesuai dengan karakter destinasi/objek daya tarik wisata.

Dinpar Kab. Bantul telah menjalin kerjasama dengan Badan Promosi Pariwisata Daerah untuk memasarkan dan mempromosikan objek daya tarik Gua Cerme.

Segala bentuk pemasaran dan promosi objek daya tarik Gua Cerme telah diverifikasi dan mendapat validasi dari pemerintah daerah.

Originalitas objek daya tarik wisata Gua Cerme sesuai/aktual.

Dinas Pariwisata Kab. Bantul melakukan diskusi dengan masyarakat lokal atau pokdarwis untuk mendapatkan umpan balik terkait promosi objek daya tarik Gua Cerme.

11 Monitoring (Pengawasan dan Pengendalian pasal 39)

Dinpar Kab. Bantul dan jajarannya diharapkan telah menggunakan sistem pengawasan, pelaporan serta respon terhadap permasalahan multidimensi yang akan berdampak negatif pada keberlanjutan pariwisata di Kawasan tersebut. Sistem pengawasan dikaji dan dievaluasi secara berkala.

Dinas Pariwisata Kab. Bantul belum memiliki suatu sistem evaluasi dan monitoring yang $\quad X$ terintegrasi.

Dinas Pariwisata Kab. Bantul melakukan kegiatan monitoring dan evaluasi 1 bulan sekali terkait kondisi terkini objek daya tarik Gua Cerme.

Hasil monitoring dan evaluasi terkait permasalahan kawasan wisata Gua Cerme tidak dapat diakses oleh publik secara luas.

Dinpar belum memiliki prosedur penanganan/mitigasi dampak pariwisata.

Besaran alokasi anggaran kegiatan monitoring dan evaluasi tercantum dalam Renstra.

12 Inventarisasi aset \& atraksi wisata

Destinasi memiliki data pencatatan aset dan atraksi yang diperbaharui secara berkala, data inventaris yang tersedia bagi masyarakat serta penilaian mengenai aset dan atraksi pariwisata, termasuk situs alam dan budaya.

Pihak Dinpar Kab. Bantul mengatakan belum melakukan inventarisasi serta klasifikasi terhadap aset di kawasan wisata Gua Cerme.

\section{Adaptasi perubahan iklim}

Dinas Pariwisata Kab. Bantul melakukan penguatan kerjasama lintas sektor untuk membentuk sistem identifikasi ancaman dan peluang terkait dengan perubahan iklim, sistem ini nantinya diharapkan dapat memberi kontribusi keberlanjutan dan ketahanan destinasi serta mengedukasi masyarakat lokal maupun wisatawan.

Belum ada upaya atau tindakan yang berkaitan dengan kearifan lokal yang dapat diperkenalkan untuk mengurangi resiko perubahan iklim. Mengingat bahwa Gua Cerme dijadikan sebagai tempat tetirah, sehingga di lokasi tedapat sampah-sampah dupa dan bekas sesaji yang justru dikhawatirkan akan mencemari sungai bawah tanah dan mengganggu ekosistem di dalam gua.

Belum ada upaya-upaya yang dilaksanakan untuk meningkatkan kesadaran masyarakat terhadap peruabahan iklim. 
Belum ada sistem yang dibuat/dirancang untuk membantu masyarakat beradaptasi dengan $\mid x$ perubahan iklim.

Program pelatihan bagi masyarakat di kawasan objek daya tarik Gua Cerme masih dalam ranah peningkatan kemampuan pengelolaan objek daya tarik, dan belum menyasar pada edukasi tentang perubahan iklim sebagai dampak dari aktifitas pariwisata.

\begin{tabular}{l|c} 
Tidak ada program yang memberikan edukasi (pelatihan,workshop, sarasehan, dsb) kepada & $X$
\end{tabular} masyarakat tentang perubahan iklim.

14 Kepuasan pengunjung

Objek daya tarik wisata Gua Cerme belum memiliki sistem atau prosedur untuk memantau tingkat kepuasan pengunjung.

Dinas Pariwisata Kab. Bantul memiliki data kunjungan wisatawan ke objek daya tarik wisata

Gua Cerme, namun sejauh ini belum ada tindaklanjut berkaitan dengan kebijakan peningkatan kepuasan wisatawan.

Adanya bagian khusus yang menangani keluhan pengunjung.

$\mathrm{X}$

$X$
Berdasarkan 14 kriteria pengelolaan pariwisata berkelanjutan, terdapat 41 poin bukti pendukung pelaksanaan pengelolaan pariwisata berkelanjutan yang telah dilaksanakan oleh Dinas Pariwisata Kabupaten Bantul. Sementara poin-poin yang belum terlaksana atau tidak memiliki bukti pendukung diantaranya berkaitan dengan,

1. Rencana pembangunan pariwisata berkelanjutan dan sistem standar dan penilaian kesesuaian pariwisata keberlanjutan.

2. Fasilitas/aksesibilitas bagi penyandang disabilitas dan kebutuhan khusus.

3. Keberadaan polisi pariwisata di kawasan wisata.

4. Rambu-rambu peringatan, akses jalan kurang lebar dan tidak memadai ketika kendaraan harus berpapasan dan area parkir terdekat kondisinya kurang memadai.

5. Pelaksanaan manajemen krisis dan kedaruratan.

6. Strategi promosi yang menerapkan prinsip-prinsip destinasi yang berkelanjutan.

7. Monitoring (pengawasan dan pengendalian) yang terintegrasi dan memiliki indikator yang jelas serta prosedur penanganan/mitigasi dampak pariwisata.

8. Inventarisasi aset dan atraksi wisata.

9. Pelaksanaan adaptasi perubahan iklim.

10. Strategi peningkatan kepuasan pengunjung.

Selain sejumlah permasalahan yang telah dipaparkan di atas, retribusi ganda menjadi kendala yang dikeluhkan oleh wisatawan.
Pengunjung yang ingin melakukan susur gua dikenakan tarif ganda berdasarkan dengan Peraturan Bupati Bantul Nomor 32 Tahun 2018 Tentang Penyesuaian Tarif Retribusi Tempat Rekreasi Pada Retribusi Tempat Rekreasi dan Olahraga. Tarif tersebut sebesar Rp 6000/orang untuk TPR Bantul dan Rp 3000/orang untuk TPR Gunung Kidul sesuai dengan Perda Kab. Gunung Kidul No. 2 Tahun 2018 tentang Retribusi Tempat Rekreasi dan Olahraga. Penetapan tarif ganda ini berlaku mengingat bahwa objek wisata Gua Cerme dikelola oleh Kabupaten Bantul dan Kabupaten Gunung Kidul. Kemudian pemangkasan alokasi anggaran untuk pengembangan objek daya tarik periode 2019 terkait dengan pelaksanaan Pilkada tahun 2020.

Kawasan objek wisata Gua Cerme merupakan area yang tergolong dalam kategori resiko rendah artinya volume sampah anorganik lingkungan objek daya tarik tersebut kecil serta jumlah vandalisme yang minim sehingga tidak mengganggu kenyamanan dan pemandangan. Sarana dan prasarana yang tersedia pun cukup untuk memenuhi kebutuhan wisatawan, diantaranya adalah 6 toilet, 1 mushola, 2 pendopo, warung-warung makan, toko souvenir, serta sejumlah rumah warga yang mulai diperbaiki dan akan difungsikan sebagai guest house. Faktor-faktor tersebut diharapkan menjadi pendorong untuk meningkatkan citra Gua Cerme sebagai objek wisata berkelanjutan. Sementara untuk mendorong tingkat jumlah kunjungan, Dinas Pariwisata Kabupaten Bantul menyelenggarakan event di Gua Cerme pada bulan Oktober tahun 2019 dengan tema "Sobo Kampung Sinau Srawung", merupakan sebuah paket wisata camping dan susur gua yang 
diselenggarakan selama dua hari pada akhir pekan. Sebagai upaya menambah daya tarik dan minat pengunjung, pihak pengelola telah menyediakan tenda camping. Masyarakat sekitar objek wisata mengharapkan kegiatan ini dapat diselenggarakan secara rutin.

\section{KESIMPULAN DAN REKOMENDASI}

Tolok ukur keberhasilan pengelolaan suatu objek daya tarik wisata tidak hanya dinilai dengan peningkatan jumlah kunjungan wisatawan, namun juga dengan kualitas pengalaman yang diperoleh wisatawan setelah mengunjungi objek daya tarik wisata. Semakin baik kualitas objek daya tarik wisata maka semakin berkualitas pengalaman yang diperoleh wisatawan. Oleh karena itu dalam rangka meningkatkan kualitas pengelolaan Gua Cerme sebagai objek daya tarik wisata berkelanjutan, rekomendasi yang dapat dilaksanakan sebagai berikut ini.

1. Kebijakan yang dikeluarkan oleh pemerintah provinsi dengan menetapkan satu otoritas pengelolaan objek wisata Gua Cerme untuk mengatasi permasalahan dualisme pengelolaan.

2. Menyusun dokumen perencanaan (masterplan) pariwisata berkelanjutan serta memberikan arah pengembangan yang tepat sesuai dengan potensi gua Cerme, segmen wisatawan yang dituju, spasial, sumber daya manusia, manajemen kunjungan, manajemen bencana, termasuk rencana untuk meningkatkan kualitas kesehatan di kawasan wisata sebagai langkah preventif jika terjadi pandemi. Sehingga kawasan gua Cerme dapat dikembangkan sebagai objek daya tarik wisata berkelanjutan.

3. Memperluas jaringan kerjasama pengembangan pemasaran dan promosi objek daya tarik wisata melalui digital marketing.

4. Menjalin kerjasama dengan pihak investor atau swasta dalam pengembangan pemasaran dan peningkatan daya jual objek wisata.

5. Menjalin kerjasama dengan lembaga akademik (perguruan tinggi yang kompeten di bidang pariwisata) dalam rangka peningkatan kualitas SDM melalui berbagai kegiatan seminar tentang pariwisata berkelanjutan, workshop meningkatkan abilitas pengelola dan masyarakat lokal terkait dengan hospitality, sertifikasi pemandu wisata khusus susur gua, dan sebagainya.

6. Menyusun indikator-indikator penilaian terkait pengawasan dan pengendalian terhadap dampak pariwisata.

7. Menyusun kuesioner atau melakukan survey untuk mengetahui kepuasan dan keluhan wisatawan sehingga dapat dilakukan tindak lanjut.

\section{DAFTAR RUJUKAN}

Adji, dkk. 1999. "Kawasan Karst dan Prospek Pengembangannya di Indonesia". Seminar PIT IGI di Universitas Indonesia, 26-27 Oktober 1999. (https://doi.org/10.31227/osf.io/ykt3f, diakses pada tanggal 16 Januari 2020).

Fandeli, C \& Mukhlison. 2000. Pengusahaan Ekowisata. Yogyakarta: Fakultas Kehutanan Univ. Gadjah Mada Yogyakarta.

International Labour Organization (ILO). 2012. Rencana Strategis Pariwisata Berkelanjutan dan Green Jobs untuk Indonesia.https://www.ilo.org/wcmsp5 /groups/public/---asia/---ro-bangkok/---ilojakarta/documents/publication/wcms_209132. pdf, diakses pada 28 Januari 2020.

Kementrian Lingkungan Hidup dan Sumber Daya Alam. 2004. "The Spectacular Tower Karst".(http://ksdae.menlhk.go.id/berita/1104/t he-spectacular-tower-karst.html, diakses pada tanggal 16 Januari 2020).

Kumar,V. 2014. Prospect of Cave Tourism in Meghalaya. Vol. 5 Issue-8 8 Year 2014 (https://www.academia.edu/19074652/PROSPE CTS_OF_CAVE_TOURISM_IN_MEGHALAYA.pdf, diakses tanggal 16 Januari 2020).

Milles, B.B \& A.M. Huberman. 1992. Analisis Data Kualitatif. Jakarta: UI Press.

Okonkwo et al.2017. Cave Tourism and its Implications to Tourism Development in Nigeria: A Case Study of Agu-Owuru Cave in Ezeagu. International Journal of Research in Tourism and Hospitality (IJRTH) Vol.3 2017. (http://dx.doi.org/10.20431/24550043.0303003, diakses pada tanggal 16 Januari 2020).

Peraturan Daerah Kab. Bantul No. 3 Tahun 2005 tentang Perizinan Usaha Jasa Pariwisata di Kabupaten Bantul.

Peraturan Daerah Kab. Bantul No. 4 tahun 2005 tentang Perizinan Usaha Obyek dan Daya tarik Wisata Alam di Kabupaten Bantul.

Peraturan Daerah Kab. Bantul No. 4 Tahun 2011 tentang Rencana Tata Ruang Wilayah Kabupaten Bantul Tahun 2010-2030

Peraturan Daerah Kab. Bantul No. 18 Tahun 2015 tentang Rencana Induk Pembangunan Kepariwisataan Daerah Kabupaten bantul 2015-2025.

Peraturan Bupati Bantul No. 84 Tahun 2016 tentang Pedoman Bantuan Keuangan kepada Desa Atas Pemanfaatan Tanah Kas Desa untuk Fasilitas Umum dalam Bentuk Dana Kompensasi Tanah Kas Desa Tahun Anggaran 2016. 
Peraturan Menteri No. 14 Tahun 2016 tentang Pedoman Pengelolaan Destinasi yang Berkelanjutan.

Peraturan Bupati Bantul No 32 Tahun 2018 Tentang Penyesuaian Tarif Retribusi Tempat Rekreasi Pada Retribusi Tempat Rekreasi dan Olahraga.

Perda Kab. Gunung Kidul No.2 Tahun 2018 tentang Perubahan Ketiga Atas Perda Kab.Gunung Kidul No. 6 tahun Tentang Retribusi Tempat Rekreasi dan Olahraga.

Purnomo, C. 2009. "Karsadag Tourism Model" Sebagai Model Pengelolaan Wisata Minat Khusus Di Kawasan Gua Cerme, Kecamatan Imogiri, Kabupaten Bantul. Jurnal Riset Daerah. Vol. VIII, No. 3. Desember 2009. Diakses melalui https://jrd.bantulkab.go.id/wp-content/ uploads/2017/02/2009jrddesember5.pdf

Rencana Strategi tahun 2016-2021 Dinas Pariwisata Kabupaten Bantul.

Sugiyono. 2007. Metode Penelitian Pendidikan Kuantitatif, Kualitatif, dan R\&D. Bandung: Alfabeta.

Sugiyono. 2014. Memahami Penelitian Kualitatif. Bandung: Alfabeta.

Usman,H \& Akbar,S. 2014. Metode Penelitian Sosial. Jakarta: Bumi Aksara 